\title{
Immunotherapy with the Vaccine Based On the Canine Neurotropic Virus (CIMT-54) For the Treatment of Cancer
}

\author{
Hugo Ramiro Segura-Puello ${ }^{1^{*}}$, Juan Sebastián Segura Charry², Diana Milena Muñoz-Forero ${ }^{3}$, Diana \\ Lorena Nieto Mosquera ${ }^{4}$ and Andrea Catalina Villamil-Ballesteros ${ }^{5}$
}

\author{
${ }^{1} \mathrm{MD}$ Research, Chief Human Research Laboratory, Manuela Beltran University, Bogotá, Colombia \\ ${ }^{2} \mathrm{MD}$ Rheumatologist, Manuela Beltran University, Bogotá, Colombia \\ ${ }^{3}$ Bacteriologist, Human Research Laboratory, Manuela Beltran University, Bogotá, Colombia \\ ${ }^{4}$ Microbiologist, Human Research Laboratory, Manuela Beltran University, Bogotá, Colombia \\ ${ }^{5}$ Veterinary, Human Research Laboratory, Manuela Beltran University, Bogotá, Colombia
}

*Corresponding author: Hugo Ramiro Segura-Puello, MD Research, Chief Human Research Laboratory, Manuela Beltran University, Bogotá, Colombia, Tel: (571)-546-0600

\begin{abstract}
The $21^{\text {st }}$ century has been the period for immunotherapy for cancer, including the use of vaccines, developed for the control of infectious agents, and now showing its usefulness also for internal agents such as cells tumors that are cloned and have accelerated mitosis states.

At Cancer Research Laboratory of Manuela Beltran University (UMB), research was carried out with the design and development of the CIMT-54 biological vaccine: A combination of oncotropic virus + amino acids as adjuvants, which act directly on the tumor cell, preventing the reproduction of metastases to other organs and preventing the attack on healthy cells of the organism. The results at preclinical level suggested that the CIMT-54 vaccine is not cytotoxic; and on the other hand, in the studies carried out in Wistar rats, it was observed that the vaccine is capable of "blocking" the tumor cells, which makes it effective to stop the metastasis, respecting the healthy tissues and organs.

A clinical study was carried out with 59 individuals, of which 21 were patients with different stages of cancer, the majority previously treated with conventional therapy. A protocol of 9 doses of the CIMT-54 vaccine was initiated, without any other type of coadjuvant treatment (by decision of the patients), in order to evaluate the safety and efficacy in the different types of cancer, managing to demonstrate the clinical and paraclinical stability of the patients, with a low rate of progression, and also improving the quality of life of the patient.
\end{abstract}

\section{Keywords}

Immunotherapy, Cancer, Vaccines, Oncolytic virus

\section{Introduction}

In general terms, two major mechanisms of immunity to tumors can be defined: Humoral and cellular. An important aspect of both is the ability of antigen-presenting cells to process and present the tumor peptides that form the basis of the immunological recognition of tumor cells. The tumor antigens are phagocytized and partially digested by the antigen-presenting cells; they are presented as peptides bound to MHC type II receptors on the surface of the antigen-presenting cell. Antigen-presenting cells include macrophages, epidermal Langerhans cells, other dendritic cells, and B-lymphocytes. The MHC type I surface receptors that form the basis of HLA tissue typing are present in all nucleated cells of the body, including the tumor cells [1-4]. These receptors present, in a quasi-random manner, examples of intracellular peptides. The MHC type I receptors of the tumor cells also present tumor-specific peptide antigens, allowing the immune system to adequately sensitize to react against the tumor [5].

For decades, the use of conventional therapies such as surgery, chemotherapy, and radiotherapy have governed the management of cancer patients [6-9]. However, there are multiple cases where a total benefit of the patients is not achieved, with new tumor relapses and/

Citation: Segura-Puello HR, Charry JSS, Muñoz-Forero DM, Mosquera DJN, Villamil-Ballesteros AC (2019) Immunotherapy with the Vaccine Based On the Canine Neurotropic Virus (CIMT-54) For the Treatment of Cancer. Int J Oncol Res 2:018. doi.org/10.23937/2643-4563/1710018

Accepted: October 14, 2019; Published: October 16, 2019

Copyright: (C) 2019 Segura-Puello HR, et al. This is an open-access article distributed under the terms of the Creative Commons Attribution License, which permits unrestricted use, distribution, and reproduction in any medium, provided the original author and source are credited. 
or adverse effects attributable to said management [10]. Alternative treatments have been considered, which allow the effective elimination of tumor cells, minimizing adverse effects, as well as tumor relapse, within which immunotherapy has emerged, as an attractive strategy. Immunotherapy includes techniques that enhance the natural immune response to tumors, through vaccines or biological response modifiers, mainly immunomodulatory cytokines [11-14].

Cancer therapeutic vaccines are based on the manipulation of the immune system in order to complement traditional oncological treatments such as chemotherapy, radiotherapy and radical surgery or they can act on their own causing the specific immune response on tumor cells, developing the ability to fight against the advancement of cancer cells $[15,16]$. At present both preventive and therapeutic vaccines have been developed [8], and are in the stage of clinical experimentation, different types of vaccines from interferons (IFN alpha, beta and gamma), interleukins (IL-2), colony stimulants factors (CEF) and monoclonal antibodies (MAb) in various types of tumors [6,17-25] .

Vaccines are today a new therapeutic alternative to counteract not only cancer but most of the chronic infectious diseases that affect the world population [26-28]. Currently, there are more than 300 vaccine studies for different types of cancer. Experimentally, in the 1960s, Wheelock and Dingle [29] (NEJM, 1964), considering acute leukemia as an entity of viral origin, carried out a protocol for the administration of viruses such as Sendai, Newcastle and strains of Influenzae A and $B$ with in order to achieve viral interference, denoting the decrease in production of myeloblasts, as well as hepatosplenic size reduction, but with very transient effect and non-sustained remission. A series of vaccines are being developed, some still in preclinical experimentation, while others are already being tested in clinical studies (Phases I, II, III and IV) [28], as in Argentina, where a vaccine called Vaccimel has been developed, for stages III and IV of melanoma with promising results, it is already being applied to a group of more than 100 patients in advanced stages [30].

There is also another type of immunotherapy, called passive [31,32], which consists of the use of the socalled Monoclonal antibodies, designed to bind specific targets called checkpoints, such as CTLA4, PD1 and PDL1, which are specific proteins and whose antibodies are anti CTLA4, anti PD1 and anti PDL1, which will cause these antibodies to bind to said proteins to block them through the $\mathrm{T}$ lymphocytes and the $\mathrm{CMH}$ of the dendritic cell, which is the antigen presenting cell-CPA [33-36]. However, this type of therapy has shown the presence of side effects, especially at the rheumatological and immunological level, but also in other systems, such as digestive, neurological, cardiopulmonary $[37,38]$. Similarly, cytokines (II-2, Interferon) were the first drugs used as a cancer treatment, but in turn, due to their high toxicity, they are not the first choice $[6,39]$. Therefore, there is a need for the use of immunotherapy mediated by oncotic viruses, where safety has been demonstrated in induction of a directed immune response, low rate of adverse effects as well as a low risk of autoimmunity associated with the use of the vaccine, and a strong oncoreactivity for stop tumor progression, and in some cases complete remission [40-45]. Several types of viruses have been evaluated, with variable results in their outcomes; particularly in the UMB, a study of several types was initiated until obtaining the best response with an oncotropic virus of canine origin, together with adjuvant amino acids, the immune complex CIMT-54 (previous in vitro tests) was achieved 1778/8.

\section{Materials and methods}

We recruited 59 individuals for the total study: 21 patients with different types of cancer and in different stages (IIIV) received the immune complex, in order to evaluate the Safety and Efficacy of the CIMT- 54 vaccine, comparing its behavior with 24 patients with cancer who did not receive the immune complex (and continued their usual conventional management), as well as two control groups: 4 healthy controls immunized with the immune complex, and 10 healthy controls not immunized, between 2007 and 2008.

After acceptance by the Ethics Committee of Manuela Beltran University (UMB), held on February 22, 2007 (document 22022007), approving the participation of patients in compassionate experimental study after checking the results obtained in preclinical studies, patients were recruited to through television information on regional channels in the country, such as City TV, RCN and radio media such as $W$ radio. It was explained to the media what the vaccine consisted of and the preclinical results that had been obtained.

A 2-hour conference was held in the UMB auditorium on how they could participate in the study, they have explained what the vaccine consisted of and the inclusion and exclusion criteria for the participants were evaluated (see Table 1).

The recruited patients signed informed consent to enter the study voluntarily. Once all the requirements were fulfilled and they were accepted in the study, a clinical history of admission was made with the laboratory examinations prior to the study. They have initially given three doses of $0.3 \mathrm{~mL}$ of a vaccine, subcutaneously weekly and then monthly reinforcements for 12 months.

Each patient was evaluated individually at 3 months from the start of treatment and then at 6, 9 and 12 months of the study with paraclinical studies (complete blood count, tumor antigens, liver tests [Transaminase, alkaline phosphatase, bilirubin], partial urine, as well as measuring Interleukins [IL-2, IL-6, IL-8, IL-10 and IL15 , as well as TNF- $\alpha$ ] with BioLegend reagent kit [ELISA 
Table 1: Inclusion and exclusion criteria.

\begin{tabular}{|c|c|}
\hline Inclusion criteria & Exclusion criteria \\
\hline $\begin{array}{ll}\checkmark & \text { Age from } 18 \text { to } 80 \text { years } \\
\checkmark & \text { Some type of cancer confirmed by pathology and } \\
\text { staged in stage III and IV. } \\
\checkmark \text { Patients who want to participate and who have no } \\
\text { difficulty to comply with the development of the study. } \\
\checkmark \text { Must have a Karnosfsky index> 50\% } \\
\checkmark \text { Life expectancy is greater than } 6 \text { months. } \\
\checkmark \text { Minimum } 4 \text { weeks must have elapsed between } \\
\text { the end of the last chemotherapy, radiotherapy, } \\
\text { glucocorticoid therapy or alternatives. } \\
\checkmark \text { No history of adverse reactions to vaccines or } \\
\text { medications. } \\
\checkmark \text { No history of allergies to medications and foods. } \\
\checkmark \text { Patients must have laboratory parameters (blood } \\
\text { count, renal function (GFR), partial urine, fasting } \\
\text { blood glucose, specific antigen and ACE. } \\
\checkmark \text { human chronic gonadotropin pregnancy test) } \\
\text { negative no more than two weeks, serology VDRL, } \\
\text { HBsAg, anti- VHC Y Elisa para VIH negatives }\end{array}$ & $\begin{array}{l}\text { - Active bleeding or uncontrolled active infection. } \\
\text { - Dx of HIV infection, viral hepatitis, tuberculosis or } \\
\text { immunosuppressed patients. } \\
\text { - Pre-existing autoimmune disease. } \\
\text { - Psychiatric illness, cognitive disability (ability to understand } \\
\text { information about the study) / social situation that would limit the } \\
\text { fulfillment of the study. } \\
\text { - Person who have participated in previous clinical studies. } \\
\text { - Women in pregnancy and/or breastfeeding } \\
\text { - Men and women of childbearing age who do not use a safe } \\
\text { method of family planning (condom with spermicide, IUD, } \\
\text { subdermal implants, oral and/or injectable contraceptives and } \\
\text { Pomeroy) } \\
\checkmark \text { - Consumers of psychoactive substances. }\end{array}$ \\
\hline
\end{tabular}

Table 2: Characterization of the population.

\begin{tabular}{|c|c|c|c|c|c|}
\hline & TOTAL & Immunized patients & $\begin{array}{l}\text { Patients not } \\
\text { immunized }\end{array}$ & Immunized controls & $\begin{array}{l}\text { Controls not } \\
\text { immunized }\end{array}$ \\
\hline Cases & 59 & 20 & 23 & 6 & 10 \\
\hline $\begin{array}{l}\text { Gender M: } \\
\mathrm{H}(\%)\end{array}$ & $\begin{array}{l}39(68.4 \%): 18 \\
(31.6 \%)\end{array}$ & $15: 5$ & $13: 10$ & $3: 1$ & $8: 2$ \\
\hline $\begin{array}{l}\text { Middle Ages } \\
\text { (years) }\end{array}$ & $45.9(+/-16)$ & $51.5(+/-14.3)$ & $48.7(+/-14.8)$ & $47.5(+-/ 19.3)$ & $27.8(+/-7.1)$ \\
\hline $\begin{array}{l}\text { Tumour } \\
\text { type }\end{array}$ & $\begin{array}{l}\text { Breast }(41.9 \%) \\
\text { Prostate }(9.3 \%) \\
\text { Colon }(9.3 \%) \\
\text { Cervix }(4.7 \%) \\
\text { Gastric }(4.7 \%) \\
\text { Osteosarcoma } \\
(4.7 \%) \\
\text { Ovary }(4.7 \%) \\
\text { Sarcoma }(4.7 \%) \\
\text { Seminoma }(4.7 \%) \\
\text { Thyroid }(4.7 \%) \\
\text { Melanoma }(2.3 \%) \\
\text { Parotid }(2.3 \%) \\
\text { Lung }(2.3 \%)\end{array}$ & $\begin{array}{l}\text { Breast }(55 \%) \\
\text { Colon }(10 \%) \\
\text { Osteosarcoma }(10 \%) \\
\text { Prostate }(10 \%) \\
\text { Sarcoma }(5 \%) \\
\text { Seminoma }(5 \%) \\
\text { Thyroid }(5 \%)\end{array}$ & $\begin{array}{l}\text { Breast }(30.4 \%) \\
\text { Cervix }(8.7 \%) \\
\text { Colon }(8.7 \%) \\
\text { Gastric }(8.7 \%) \\
\text { Ovary }(8.7 \%) \\
\text { Prostate }(8.7 \%) \\
\text { Melanoma }(4.3 \%) \\
\text { Parotid }(4.3 \%) \\
\text { Lung }(4.3 \%) \\
\text { Sarcoma }(4.3 \%) \\
\text { Seminoma }(4.3 \%) \\
\text { Thyroid }(4.3 \%)\end{array}$ & N/A & N/A \\
\hline $\begin{array}{l}\text { Tumoral } \\
\text { Stadium (\%) }\end{array}$ & $\begin{array}{l}\text { I: } \mathbf{2} \% \\
\text { II: } \mathbf{3 3} \% \\
\text { III: } \mathbf{3 7 \%} \\
\text { IV: } 28 \%\end{array}$ & $\begin{array}{l}\text { I: } 25 \% \\
\text { II: } 40 \% \\
\text { III: } 5 \% \\
\text { IV: } 30 \%\end{array}$ & $\begin{array}{l}\text { I: } 13 \% \\
\text { II: } 47.8 \% \\
\text { III: } 30.4 \% \\
\text { IV: } 8.6 \%\end{array}$ & N/A & $\mathrm{N} / \mathrm{A}$ \\
\hline
\end{tabular}

kit with human interleukins, San Diego, CA 92121]) for the analysis at admission with active tumor status (and also baseline measurement in immunized and non-immunized controls), and subsequent follow-up at 12 months. Additionally, studies of diagnostic images (MRI, $\mathrm{CT}, \mathrm{Rx}$, ultrasound) were ordered according to the type of cancer.
Safety was evaluated, defined as absence of side effects adverse to the use of the CIMT-54 vaccine at a dose of $0.3 \mathrm{ml}$ determined in the in vitro study as the adequate dose for the patients in question, as well as the effectiveness of the product, defined as achieving a condition of stability (no changes) or improvement of the oncological process (partial remission or com- 
plete remission) according to WHO and RECIST criteria for response in solid and hematological tumors $[46,47]$ (see Table 2). Follow-up of tumor markers in response was also performed $[48,49]$, and interleukin monitoring throughout the entire process to determine the antitumor effect associated with the vaccine.

\section{Results}

Of the 57 total cases, $68.4 \%$ were women and $31.6 \%$ men, average age 45.9 years (+/- 16), with breast can- cer as predominant tumor (41.9\%), in large percentage in advanced tumor stages (stage IV $28 \%$, stage III $37 \%$, see Table 2). Patients evaluated during and after treatment with the vaccine showed that it was safe, given the absence of side effects attributable to the use of the immune complex, and was effective in clinical and paraclinical stability (see Figure 1 and Figure 2), regardless of the tumor type and of the presented stadium. There was even a great response in terms of partial remission (improvement) and no changes (stability) in patients in

\section{IMAGING STAGE FOLLOW-Up}

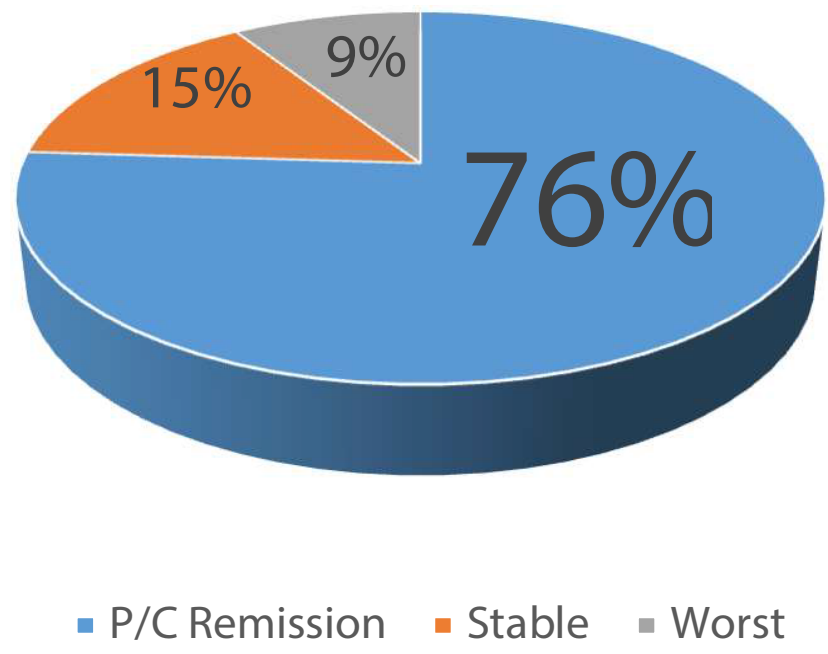

Figure 1: Imaging Follow-up (P/C: partial/complete).

A several group of patients keep on stability after the CIMT-54 use, with only a $9 \%$ of progression of the disease.

\section{TUMORAL ANTIGEN FOLLOW-UP}

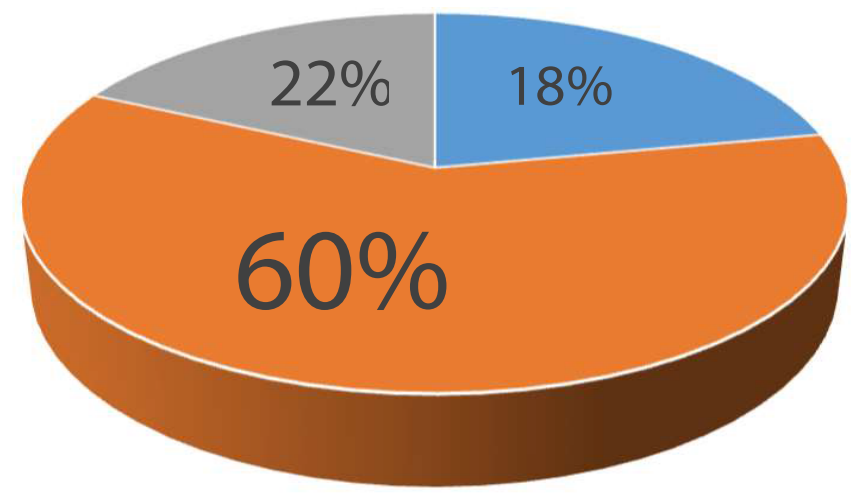

- $\mathrm{P} / \mathrm{C}$ Remission - Stable $=$ Worst

Figure 2: Tumoral antigen Follow-up (P/C: partial/complete).

A $60 \%$ of the patients reach stability of the tumoral antigens as a marker of control of the inflammatory activity of the cancer, with a $22 \%$ with progression (worst). 


\section{CLINICAL BEHAVIOR ON FOLLOW-UP}

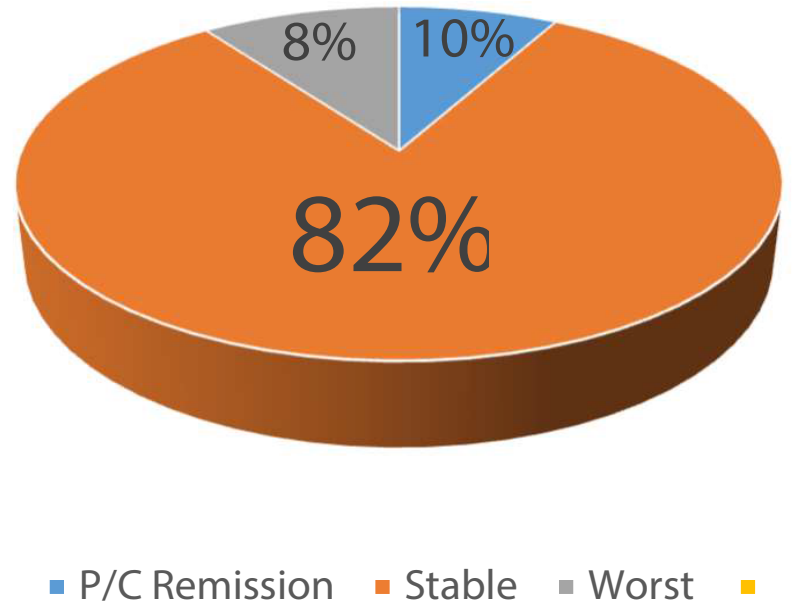

Figure 3: Clinical Follow-up (P/C: partial/complete).

In general, the clinical behavior of the patients match criteria for stability in $82 \%$ of the cases, with a $8 \%$ of progression.

\section{CLINICAL FOLLOW-UP STAGE-BASED}

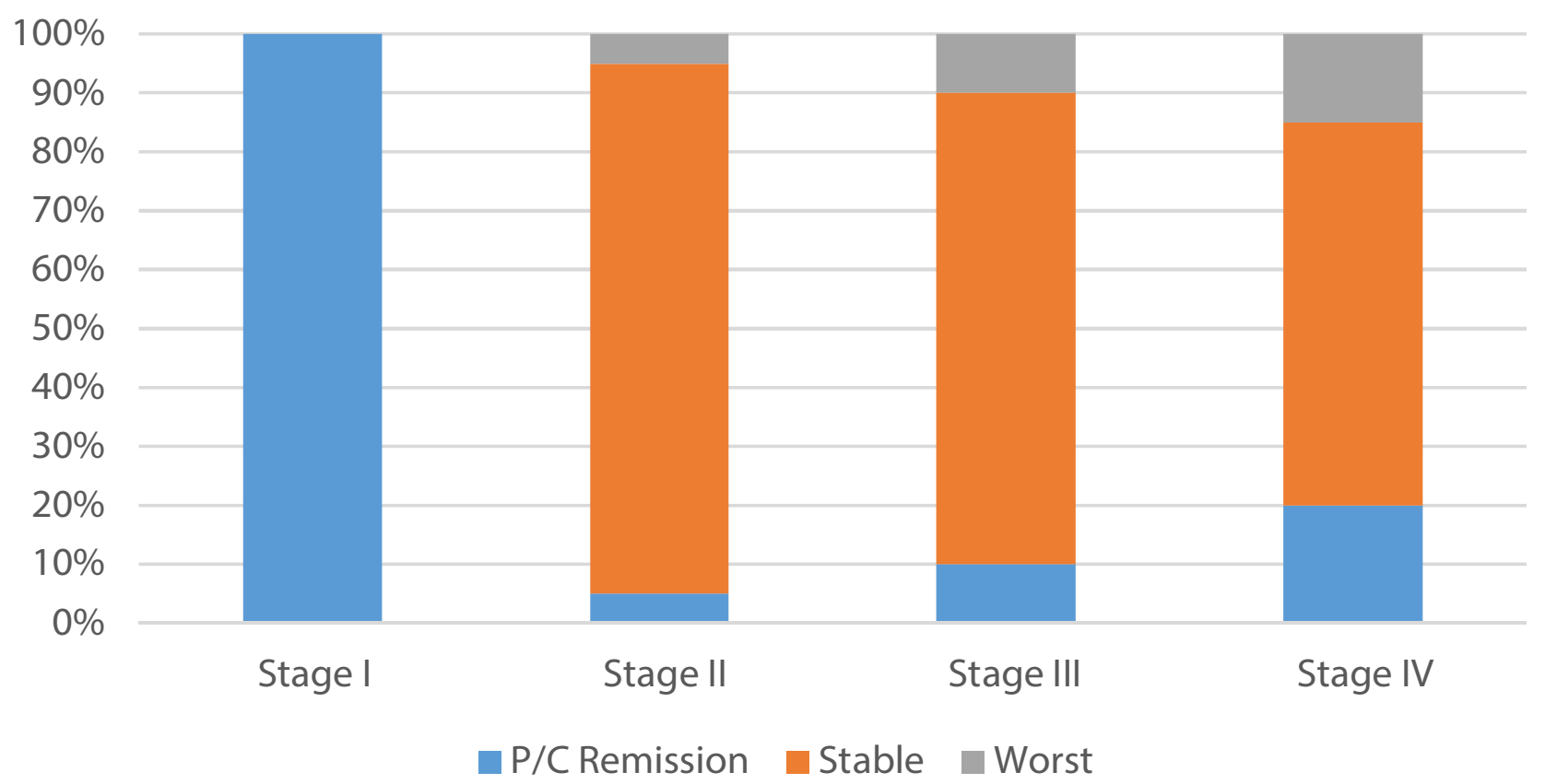

Figure 4: Clinical behavior Tumor stage-based (P/C: partial/complete).

Comparing tumoral stages, we observed that the clinical stability was similar, with a low rate of progression, more evident in advanced stage (IV), and with total remission en early stage (I).

stages III and IV (see Figures 3 and Figure 4), which is an interesting finding, given that some of the cases had already been declared "patients with no possibility of treatment in a conventional manner", due to the advanced stage of the disease. Additionally, the behavior of the Interleukins, at 12-month control, in cancer patients who received the immune complex, demonstrated a decrease in IL-2 expression (by $58 \%$ compared to sick patients not immunized), IL-6 (in $82 \%$ compared to sick patients not immunized), IL-8 (in 76\% compared to sick patients not immunized), and TNF- $\alpha$ (in $75 \%$ compared to sick patients not immunized), being the cytokines keys in tumor growth, tumor progression, antitumor immune resistance as a mechanism of evasion, maintaining stable levels of IL-10 and IL-15 (promoters of antitumor cytotoxicity, as well as blocking tumor growth). See Figure 5. 


\section{INTERLEUKINS FOLLOW-UP}

\section{0}

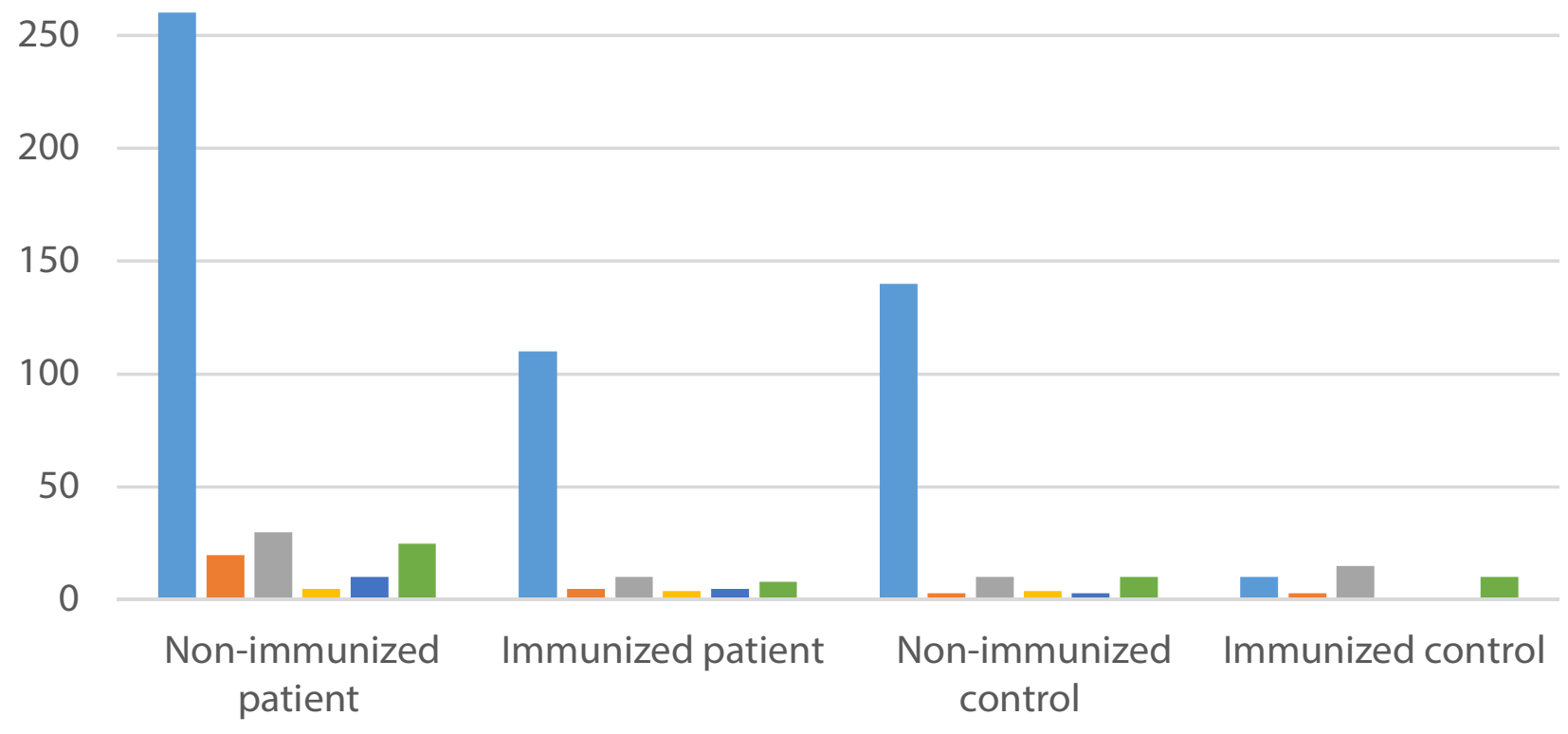

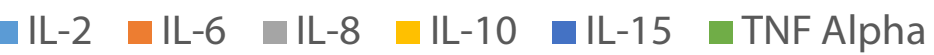

Figure 5: Interleukin's (pg/dL) on patient's vs. controls Follow-up.

A comparison between IL-s between patients immunized and non-immunized, demonstrate that CIMT-54 reduce the expression of IL-2, IL-6, IL-8, as a markers of inflammatory tumoral activity, with stability of IL-10, IL-15 as promoters of antitumor cytotoxicity.

\section{Discussion}

Previous studies performed in vitro tests with tumor cells show morphological evidence of cell adhesion and interruption of mitosis, stimulation of adhesion molecules (cadherins, adhesin, connexins) when the vaccine was applied in 3 doses, not allowing these cells they continued dividing by mitosis, thus avoiding the tumor progression towards metastasis.

$84 \%$ of the patients in our study had received some type of conventional treatment (Chemotherapy, Radiotherapy and/or surgery), while $16 \%$ on admission had not received any treatment, regardless of the stage in which they were.

The established dose/response of the vaccine was $0.3 \mathrm{~mL}$. This was applied to the group of patients, with no noticeable side effects or anaphylactic reactions. The CIMT-54 vaccine was applied in three initial doses, with an interval of 1 week between each and with monthly reinforcements, in a period of 12 months, observing a promising response that allowed to project the efficacy of the CIMT-54 vaccine and justify the clinical trial that we call a case study, because, with the results in preclinical phase that was also very promising, it was concluded that the CIMT-54 vaccine was not cytotoxic in the in vitro studies, nor toxic in the experimental animals at the dose $0.3 \mathrm{~mL}$, after sufficient tests were performed that allowed the adjustment of the dose/response.

The administration of 9 doses of the CIMT-54 vaccine at the established dose, without other coadjuvant treatment, allows us to infer that the treatment with the CIMT-54 vaccine was successful, both in prolonging and improving the quality of life of the patient, without receiving no complementary treatment, as well as maintaining clinical and paraclinical stability indexes, which would make it possible for the CIMT-54 vaccine to be an effective and economical alternative in the treatment of cancer, especially in those cases of early detection, finding an scientific option for patients in terminal stages $[50,51]$. We believe that therapy with the CIMT-54 vaccine is promising to prevent and treat cancer. The limitations in our study are focused on the few immunological tests that were carried out, given technical and logistical difficulties with higher technology equipment, which would give a much broader richness to the beneficial effects of the vaccine, as well as allow us under a more detailed analysis, the possibility of evaluating which type of tumors can have a greater response based on the oncotrophic mechanism of the virus, and by which routes.

\section{Conclusion}

There are several questions: 
1. What type of immunotherapy would be the most appropriate for patients with cancer?

2. Having shown in this case that vaccines have fewer side effects for cancer patients, could they be more effective than monoclonal antibodies?

3. The problem with vaccines for cancers takes much longer to produce a response and be effective than chemotherapy itself. Could this be a limitation for its use?

4. Could the side effects of monoclonal antibodies be improved to make them more effective?

5. Would vaccines reduce treatment costs and allow a greater field of action, unlike monoclonal antibodies, taking into account the direct costs, accessibility, and barriers of the health system?

\section{Conflicts of Interest}

The authors declare that they have no competing interests.

\section{References}

1. Finn OJ (1994) Tumor-specific immune responses and opportunities for tumor vaccines. Clin Immunol Immunopathol 71: 260-262.

2. Tan TT, LM Coussens (2007) Humoral immunity, inflammation and cancer. Curr Opin Immunol 19: 209-216.

3. Kalluri R, M Zeisberg (2006) Fibroblasts in cancer. Nat Rev Cancer 6: 392-401.

4. Sultan M, Coyle KM, Vidovic D, Thomas ML, Gujar S, et al (2017) Hide-and-seek: The interplay between cancer stem cells and the immune system. Carcinogenesis 38: 107-118.

5. Amanna IJ, Slifka MK (2011) Contributions of humoral and cellular immunity to vaccine-induced protection in humans. Virology 411: 206-215.

6. Caspi RR (2008) Immunotherapy of autoimmunity and cancer: The penalty for success. Nat Rev Immunol 8: 970-976.

7. Lipson EJ, Forde PM, Hammers HJ, Emens LA, Taube JM, et al. (2015) Antagonists of PD-1 and PD-L1 in Cancer Treatment. Semin Oncol 42: 587-600.

8. Rius M, F Lyko (2012) Epigenetic cancer therapy: Rationales, targets and drugs. Oncogene 31: 4257-4265.

9. Sharma P, Hu-Lieskovan S, Wargo JA, Ribas A (2017) Primary, Adaptive, and Acquired Resistance to Cancer Immunotherapy. Cell 168: 707-723.

10. Zugazagoitia J, Guedes C, Ponce S, Ferrer I, Molina-Pinelo S, et al. (2016) Current Challenges in Cancer Treatment. ClinTher 38: 1551-1566.

11. Guo ZS, Liu Z, Kowalsky S, Feist M, Kalinski P, et al. (2017) Oncolytic Immunotherapy: Conceptual Evolution, Current Strategies, and Future Perspectives. Front Immunol 8: 555.

12. Finn OJ (2018) The dawn of vaccines for cancer prevention. Nat Rev Immunol 18: 183-194.

13. Lakshmi Narendra B, Eshvendar Reddy K, Shantikumar S, Ramakrishna S (2013) Immune system: a double-edged sword in cancer. Inflamm Res 62: 823-834.

14. Vesely MD, Schreiber RD (2013) Cancer immunoediting: antigens, mechanisms, and implications to cancer immuno- therapy. Ann N Y Acad Sci 1284: 1-5

15. Adair RA, Roulstone V, Scott KJ, Morgan R, Nuovo GJ, et al. (2012) Cell carriage, delivery, and selective replication of an oncolytic virus in tumor in patients. Sci Transl Med 4: 138 ra77.

16. Ye Z, Qian Q, Jin H, Qian Q (2018) Cancer vaccine: learning lessons from immune checkpoint inhibitors. J Cancer 9: 263-268.

17. Andtbacka RH, Kaufman HL, Collichio F, Amatruda T, Senzer N, et al. (2015) Talimogene Laherparepvec Improves Durable Response Rate in Patients With Advanced Melanoma. J Clin Oncol 33: 2780-2788.

18. Barve M, Bender J, Senzer N, Cunningham C, Greco FA, et al. (2008) Induction of immune responses and clinical efficacy in a phase II trial of IDM-2101, a 10-epitope cytotoxic T-lymphocyte vaccine, in metastatic non-small-cell lung cancer. J Clin Oncol 26: 4418-4425.

19. Carew JF, Kooby DA, Halterman MW, Kim SH, Federoff $\mathrm{HJ}$, et al. (2001) A novel approach to cancer therapy using an oncolytic herpes virus to package amplicons containing cytokine genes. Mol Ther 4: 250-256.

20. Parato KA, Breitbach CJ, Le Boeuf F, Wang J, Storbeck C, et al. (2012) The oncolytic poxvirus JX-594 selectively replicates in and destroys cancer cells driven by genetic pathways commonly activated in cancers. Mol Ther 20: 749-758.

21. Platanias LC (2005) Mechanisms of type-I- and type-II-interferon-mediated signalling. Nat Rev Immunol 5: 375-386.

22. Pol J, Kroemer G, Galluzzi L (2016) First oncolytic virus approved for melanoma immunotherapy. Oncoimmunology 5: e1115641.

23. Sing AP, Ambinder RF, Hong DJ, Jensen M, Batten W, et al. (1997) Isolation of Epstein-Barr virus (EBV)-specific cytotoxic $\mathrm{T}$ lymphocytes that lyse Reed-Sternberg cells: implications for immune-mediated therapy of EBV+ Hodgkin's disease. Blood 89: 1978-1986.

24. van der Burg SH, CJ Melief (2011) Therapeutic vaccination against human papilloma virus induced malignancies. CurrOpinlmmunol 23: 252-257.

25. Dranoff G (2004) Cytokines in cancer pathogenesis and cancer therapy. Nat Rev Cancer 4: 11-22.

26. Whiteside TL, Demaria S, Rodriguez-Ruiz ME, Zarour HM, Melero I (2016) Emerging Opportunities and Challenges in Cancer Immunotherapy. Clin Cancer Res 22: 1845-1855.

27. Wong KK, Li WA, Mooney DJ, Dranoff G (2016) Advances in Therapeutic Cancer Vaccines. Advlmmunol 130: 191249.

28. Zhang $\mathrm{H}$, Chen $\mathrm{J}$ (2018) Current status and future directions of cancer immunotherapy. J Cancer 9: 1773-1781.

29. Wheelock EF, JH Dingle (1964) Observations on the repeated administration of viruses to a patient with acute leukemia. A preliminary report. N Engl J Med 271: 645-651.

30. Barrio MM, de Motta PT, Kaplan J, von Euw EM, Bravo Al, et al. (2006) A phase I study of an allogeneic cell vaccine (VACCIMEL) with GM-CSF in melanoma patients. J Immunother 29: 444-454.

31. Dustin ML (2016) Cancer immunotherapy: Killers on sterols. Nature 531: 583-584.

32. Munhoz RR, Postow MA (2016) Recent advances in understanding antitumor immunity. F1000Res 5: 2545. 
33. Gul N, M van Egmond (2015) Antibody-Dependent Phagocytosis of Tumor Cells by Macrophages: A Potent Effector Mechanism of Monoclonal Antibody Therapy of Cancer. Cancer Res 75: 5008-5013.

34. Henricks LM, Schellens JH, Huitema AD, Beijnen JH (2015) The use of combinations of monoclonal antibodies in clinical oncology. Cancer Treat Rev 41: 859-867.

35. Jeanbart L, Swartz MA (2015) Engineering opportunities in cancer immunotherapy. Proc Natl Acad Sci U S A 112: 14467-14472.

36. Maeda E, Urakami K, Shimura K, Kinoshita M, Kakehi K, et al. (2010) Charge heterogeneity of a therapeutic monoclonal antibody conjugated with a cytotoxic antitumor antibiotic, calicheamicin. J Chromatogr A 1217: 7164-7171.

37. Amos SM, Duong CP, Westwood JA, Ritchie DS, Junghans $\mathrm{RP}$, et al. (2011) Autoimmunity associated with immunotherapy of cancer. Blood 118: 499-509.

38. Shore ND (2015) Advances in the understanding of cancer immunotherapy. BJU Int 116: 321-329.

39. Floros T, Tarhini AA (2015) Anticancer Cytokines: Biology and Clinical Effects of Interferon-alpha2, Interleukin (IL)-2, IL-15, IL-21, and IL-12. Semin Oncol 42: 539-548.

40. Cho IR, Kaowinn S, Moon J, Soh J, Kang HY, et al. (2015) Oncotropic $\mathrm{H}-1$ parvovirus infection degrades HIF-1alpha protein in human pancreatic cancer cells independently of VHL and RACK1. Int J Oncol 46: 2076-2082.

41. Dupont F, Avalosse B, Karim A, Mine N, Bosseler M, et al (2000) Tumor-selective gene transduction and cell killing with an oncotropic autonomous parvovirus-based vector. Gene Ther 7: 790-796.

42. Grekova SP, Rommelaere J, Raykov Z (2012) Parvovirus- es-tools to fine-tune anticancer immune responses. Oncoimmunology 1: 1417-1419.

43. Liu GB, Zhao L, Zhang L, Zhao KN (2017) Virus, Oncolytic Virus and Human Prostate Cancer. Curr Cancer Drug Targets 17: $522-533$.

44. Raykov Z, Grekova S, Galabov AS, Balboni G, Koch U, et al. (2007) Combined oncolytic and vaccination activities of parvovirus $\mathrm{H}-1$ in a metastatic tumor model. Oncol Rep 17: 1493-1499.

45. Samsoniia MD, Gibradze OT, Kandelaki MA, Chankseliani GS, Tevdoradze DI (2011) Oncotropic viruses and antitumor autovaccines (review). Georgian Med News 194: 19-23.

46. Miller AB, Hoogstraten B, Staquet M, Winkler A (1981) Reporting results of cancer treatment. Cancer 47: 207-214.

47. Robertson JF, Pearson D, Price MR, Selby C, Blamey RW, et al. (1991) Objective measurement of therapeutic response in breast cancer using tumour markers. Br J Cancer 64: 757-763.

48. Cheung KL, Graves CR, Robertson JF (2000) Tumour marker measurements in the diagnosis and monitoring of breast cancer. Cancer Treat Rev 26: 91-102.

49. Robertson JF, Jaeger W, Syzmendera JJ, Selby C, Coleman R, et al. (1999) The objective measurement of remission and progression in metastatic breast cancer by use of serum tumour markers. European Group for Serum Tumour Markers in Breast Cancer. Eur J Cancer 35: 47-53.

50. Yu Y, Cui J (2018) Present and future of cancer immunotherapy: A tumor microenvironmental perspective. OncolLett 16: 4105-4113.

51. Speiser DE, Flatz L (2014) Cancer immunotherapy drives implementation science in oncology. Hum Vaccin Immunother 10: 3107-3110. 